\title{
Exploring the Possible Applicability of Yagya in Present Time: A Review
}

\author{
Vandana Shrivastava ${ }^{1}$, Saurabh Mishra ${ }^{2, *}$, Alka Mishra $^{1}$ \\ 1. Department of Ayurveda and Holistic Health, Dev Sanskriti Vishwavidyalaya, \\ Gayatrikunj-Shantikunj, Haridwar, Uttarakhand, India \\ 2. Dev Sanskriti Vishwavidyalaya, Gayatrikunj-Shantikunj, Haridwar, Uttarakhand, India
}

"Corresponding author: Saurabh Mishra - Email: sau.dsvv@gmail.com

\section{Cite this research article as follows:}

Shrivastava V, Mishra S, Mishra A. Exploring the Possible Applicability of Yagya in Present Time: A Review. Ayurveda evam Samagra Swasthya Shodhamala. 2020;2(2):1. [cited date]. Available from: https://sites.google.com/dsvv.ac.in/shodhamala-dahh/asssm22/asssm221

\section{License information for readers:}

The original contents published in this research publication, which include research articles, case reports, etc., are published under the Creative Commons Attribution (CC BY 4.0) License. Anyone may reproduce, distribute, translate and create derivative works of this original content, subject to full attribution to the original research publication (Ayurveda evam Samagra Swasthya Shodhamala) and authors. The full terms of this license may be seen at https://creativecommons.org/licenses/by/4.0/

\section{Published by:}

Department of Ayurveda and Holistic Health

Dev Sanskriti Vishwavidyalaya

Gayatrikunj-Shantikunj, Haridwar - 249411

Uttarakhand, India

Email: dahh@dsvv.ac.in

Mobile: +91 9258360953, +918954890390

Website: http://www.dsvv.ac.in/dahh

Published online: 4 June 2020 


\begin{abstract}
Yagya has been one of the core elements of the ancient Indian Culture ever since the Vedic era, and is also an effective therapeutic procedure. The present review article explores the applicability of Yagya during the present time, wherein the principles, procedure and the possible mode of action of Yagya have been described; the efficacy of Ayurvedic medicines and medicinal herbs in the management of various diseases caused by viruses, as well as the diseases that have symptoms similar to those prevalent during present time, have been discussed; the ethnobotanical use of herbal fumigation in the management of various diseases, has been presented; as well as, the efficacy of Yagya Therapy / Integrative approach (including Yagya Therapy) in the management of symptoms of various disease conditions has been illustrated. The review also briefly illustrates the ancient Ayurvedic perspective about epidemics and the possible role of Yagya as a management approach for the same. Based on the information presented herein, the applicability of Yagya in the present time seems to be a promising possibility, that is worth exploring further through proper experimentation and analysis.
\end{abstract}

Keywords: Pandemic, Epidemic, Infectious Diseases, Public Health, Environment Purification, Yagya, Ayurveda, Herbs, Mantra, Traditional Medicine 


\section{Introduction}

The present review article explores the possible applicability of Yagya in the present time, which has been one of the core elements of the ancient Indian Culture ever since the Vedic era, and is also an effective therapeutic procedure. The review has been divided into the following sections, as listed below.

1 Introduction of Yagya and its mode of action

2 Interventions involving medicinal herbs and Ayurvedic medicines

2.1 Ayurvedic advisories about some diseases caused by viruses

2.2 Evidence based Ayurvedic management of various diseases

2.3 Studies on the therapeutic efficacy of various Ayurvedic interventions and medicinal herbs for the management of diseases that have symptoms similar to those prevalent during present time

3 Ethnobotanical Review of Medicinal Plants Used in Different Countries - Use of Herbal Fumigation for Various Diseases

4 Studies indicating the efficacy of Yagya Therapy / Integrative Approach (including Yagya Therapy) in the management of symptoms of various disease conditions

5 Ayurvedic perspective about epidemics and the therapeutic effects of Yagya / Herbs / Mantra as mentioned in ancient Vedic scriptures

5.1 Causes and symptoms of epidemics

5.2 Suggested management of diseases that affect people during epidemics

5.3 How does Yagya incorporate the management measures suggested above?

5.4 References from ancient Vedic scriptures that describe the therapeutic effects of Yagya / Herbs / Mantra

\section{Introduction of Yagya and its mode of action}

Yagya is an ancient Indian therapeutic procedure, which nurtures nature's ecological balance, resulting in all-round well-being of an individual, as well as the entire cosmos [1].

\subsection{Subtle and emotional aspects of Yagya affecting a person}

With regards to the subtle and emotional aspects of Yagya affecting a person, the feeling of 'giving' is inherently associated with Yagya, i.e. feeling, understanding and acknowledging that a person is an inseparable constituent of the nature and society, has immensely benefited from these throughout life, and hence, it is the duty of the person to give a part of one's compassion, feelings, endeavors, resources, etc. for the betterment of the nature and society; this sense of responsibility significantly contributes to the positive restructuring of the psyche of the person, leading to an all round physical, mental and emotional well being; also, the nature reciprocates these feelings, which further contributes to the overall betterment of the person [1-4]. 


\subsection{Therapeutic effect of herbal medicinal fumes generated in Yagya}

In the process of Yagya, coarse powder made up of dry plant-medicines (havan samagri), as well as selected nutritious and aromatic substances, undergoes transformation into vapor phase; these phytomedicines spread along with the volatile substances and gases, released by the slow and controlled combustion process in Yagya fire [1-4]. In addition, frequent oral and nasal inhalation of phytomedicines, present in the medicinal-fumes generated in Yagya, takes place because of the rhythmic deep breathing exercise (pranayama) and chanting of certain Vedic hymns (Mantras) by the subjects (patients) throughout the duration of the Yagya, which contributes to the efficient pulmonary administration of phytomedicines, and the desired therapeutic benefit [1-4].

In order to understand the composition of the herbal mixture (havan samagri) used for the treatment of a specific disease, it is necessary to understand the Ayurvedic (ancient traditional Indian medical science - Ayurveda) perspective with regards to the diagnosis of diseases and their treatment.

According to Ayurveda, a healthy human body is supposed to have a relatively stable equilibrium (congenial homeostasis) of Dosha (psycho-biological rhythm - Vata, Pitta, Kapha), Agni (digestion and metabolism), Dhatu (body tissues and their nourishing elements) and Mala (excreta), as well as the well being of soul, senses and mind [5-9]. Imbalance in this equilibrium leads to disease, which may be due to internal reasons like weakness, etc., or due to external factors, like bacteria, virus, other pathogens, particulate matter, etc.; the aim of the therapy is to restore this balance [5-9].

Thus, Ayurveda restores the natural equilibrium of the body, mind and soul, because of which the vitality of an individual is restored, and the disease causing elements like virus, bacteria, etc. become ineffective.

Several studies, that illustrate the therapeutic efficacy of various Ayurvedic interventions and medicinal herbs in the management of the diseases that have symptoms similar to those prevalent during present time, have been discussed briefly in Section 2 of this article.

Thus, the ingredients of the herbal mixture (havan samagri) used in the Yagya have properties of pacifying the vitiated elements present in a person, providing strength and rejuvenation, leading to the relief in various disease symptoms; in this manner, their vapors help in the treatment of the disease condition [1-4].

Vedic texts mention the use of herbal fumes generated from Yagya for health benefits, as well as purification of environment [1-4]. Yagya (which includes generation of herbal medicinal fumes) has been widely used in India to combat seasonal epidemics and purify the environment [1-4]. Herbal fumes (Dhoomnasya) are regularly used in Ayurveda as effective approaches for restoration of health $[7,8]$.

In modern times, several studies depict the ethnobotanical use (in different countries) of herbal fumes for therapeutic purposes; some such studies have been discussed briefly in Section 3 of this article. 


\subsection{Effect of Vedic hymns (Mantras) chanted during Yagya}

The Vedic hymns (Mantras) chanted during Yagya are intense spiritual prayers to the Almighty for the well being of both the self, as well as the entire cosmos [1-4,10,11]. During the chanting of these Mantras, the participants are supposed to continuously meditate on their meaning; thus, this chanting creates a continuous process of meditation and contemplation, which contributes to the positive restructuring of the psyche of the participants $[1-4,10,11]$. The Mantras have a unique combination of syllables and words, which when chanted in a rhythmic manner, lead to the creation of distinct and powerful sound waves that contribute to the desired therapeutic benefit on the physical, mental and emotional level $[1-4,10,11]$. The chanting of Gayatri Mantra causes beneficial effects with regards to various physical, mental and emotional conditions [1-4,10,11].

\subsection{Effect of bright light and heat of Yagya fire}

During Yagya, the patient has to sit near the Yagya fire for a specified amount of time; this way, the patient experiences the bright light and heat of the fire [1-4], which have their own therapeutic advantages.

\subsection{Subtle working principle of Yagya}

With regards to the subtle working principle of Yagya, it aims to acquire the prana (vital life force $[12,13]$ ) from the cosmos, and regulate its flow in the body, for overall well being [1]. Similar principles are found in various other ancient traditions and medicinal practices of both India and abroad, such as Chinese Medicine, Varmakkalai (a branch of Siddha system of South Indian Traditional Medicine), Ayurveda, Marma Therapy, Yagya Therapy, Yoga, etc. 'qi' is the vital substance of life in Chinese philosophy; 'qi' circulates in channels (mai) throughout the body according to acupuncture and moxibustion theories, in which qi is also central to diagnostic and therapeutic techniques; Tuina massage and acupressure, for instance, also aim at equalizing qi through stimulation [14]. As per the philosophy of Varmakkalai, 'piranam' (prana), the root of human existence, circulates via a system of channels through the body, the 'nati' (Sanskrit 'nadi') channels. If unbalanced, practitioners of vital spot medicine attempt to equalize the flow of piranam by stimulating varmam loci, which lie on nati channels, and are therefore spots of concentrated piranam force [14]. Similarly, in Marma Therapy of Ayurveda, the flow of prana in the body is rectified by stimulating vital spots in the body, called Marma [14]. About the Yogic practice of Pranayama, Hatha Yoga Pradipika $(2 / 5)$ [15] states that when all the dirty Nadis (subtle veins and nerves) are purified, then only a Sadhak (practitioner of spirituality) becomes capable of properly controlling the prana. The Ayurvedic medicines and therapies also aim to regain the balance of the Doshas (bio-humors) and other vital elements, which in turn ascertains proper coordination between the body, mind and soul $[5,7]$.

Thus, Yagya Therapy (Yagyopathy) presents a multi-modal approach for the treatment of diseases.

In this regard, several studies, that illustrate the application and efficacy of Yagya in the management of symptoms of various disease conditions, have been briefly discussed in Section 4 of this article. 
The historical perspective about epidemics and the possible role of Yagya as a remedial measure for the same, have been briefly discussed in Section 5 of this article.

\subsection{Suggested Method of doing Yagya}

Science and Philosophy of Yagya can be read from [1]. The Procedure of Yagya, along with the mantras, their meanings and the associated feelings have been described in [10]. The audio of Yagya Procedure can be accessed from [http://audio.awgp.org/album/play/43_yagya_karmkand]. After the completion of Yagya, the participants are required to do Pranayama for about 15 minutes in its vicinity.

If possible, the following herbal ingredients [http://www.awgp.org/] (or whichever are available) may be used in the herbal mixture (havan samagri) for Yagya; these herbs have known beneficial effects with regards to various disease conditions including respiratory diseases and associated ailments [7,16], as well as purification of environment [1]:

Tulasi (Ocimum tenuiflorum), Giloy (Tinospora cordifolia), Kalmegh (Andrographis paniculata), Neem (Azadirachta indica), Jatamansi (Nardostachys jatamansi), Jayphal and Javitri (Myristica Fragrans), Nagarmotha (Cyperus scariosus), Clove (Syzygium aromaticum), Daruhaldi (Berberis aristata), Devdaru (Cedrus deodara), Kapoor (Bhimseni) (Cinnamomum Camphora), Sugandhbala (Valeriana jatamansi Jones (Syn. V. wallichii DC.)), Agar (Aquilaria malaccensis), Tagar (Valeriana jatamansi), Agya Ghas (Cymbopogon martini).

In case it is not feasible to do Yagya physically, then one can listen to the Audio of the Yagya Procedure given above, and mentally / emotionally perform the Yagya - the Mantras and the feelings associated with them have their own benefits [11].

The various aspects of Yagya mentioned above are being described briefly in the following sections.

\section{Interventions involving medicinal herbs and Ayurvedic medicines}

\subsection{Ayurvedic advisories about some diseases caused by viruses}

2.1.1 An advisory titled 'Ayurvedic advocacy for management of Nipah Virus (NiV)

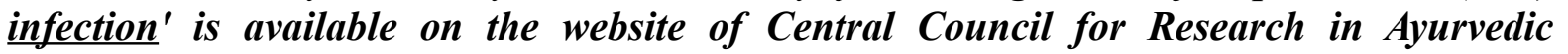
Sciences (CCRAS), Ministry of AYUSH, Government of India [17]. The details of this advisory are as follows.

Nipah virus (NiV) is a paramyxovirus transmitted to humans from animals, which have been affected by this virus. It can also be transmitted from infected humans to other humans through direct contact.

$\mathrm{NiV}$ causes a symptomatic or mild infection in some of the patients, but most of the clinical cases present with acute neurological signs and symptoms. The initial symptoms appear are influenza like, with high fever, headache, and myalgia.

In Ayurvedic perspectives, it comes under the category of Vata Shlaishmik Jwara initially, which further extends to Sannipataja Jwara. 
Prophylatic Measures / Immunomodulatory drugs

- Measures should be taken to strengthen the immune system through healthy dietic habits.

- Amlaki Rasayana 3 gm, twice a day with water.

- Ashwagandadi Avaleha 10 gm twice a day with lukewarm milk.

- Haridra khand 5 gm twice a day with lukewarm milk.

- Samshamani vati $500 \mathrm{mg}$ twice a day.

- Tulasi 3-5 leaves should be consumed a fresh or in tea twice in a day.

- Indukantha kashay $10 \mathrm{ml}$ with $40 \mathrm{ml}$ of warm water twice a day before food.

For Fever, Headache, and Myalgia

- Amritottar kashaya $30 \mathrm{ml}$ twice a day

- AYUSH- 64/Sanjivini vati 2 tablet thrice a day.

- Bilwadi gutika 2 tablet twice a day.

- If symptoms of upper respiratory tract involvement is present - AYUSH-64 with Tribhuvan Kirti Rasa.

High Fever with early neurological symptoms

- Swarna Sutshekhar Rasa $125 \mathrm{mg}$ twice a day with honey for 7 days.

- Swarna Malti Rasa 125 mg twice a day with honey .

For Hydration

- Shadang Paniya/Drakshadi kwatha

Note

- The dose and duration of the treatment may be decided by the physician according to the age and condition of the patient.

This advocacy is for information only. However, the health seekers may approach a qualified registered Ayurveda medical practioner for necessary advice.

2.1.2 An advisory titled 'Avurvedic perspective of swine flu' is available on the website of National Health Portal (NHP), Centre for Health Informatics, National Institute of Health and Family Welfare, Ministry of Health and Family Welfare, Government of India [18]; the details of the same may be read at this webpage [18].

2.1.3 An advisory titled 'Ayurveda's immunity boosting measures for self care during -

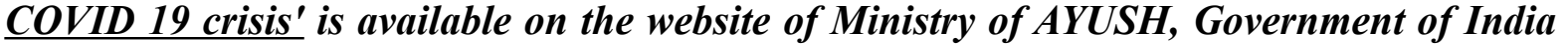
[19]. The details of this advisory are as follows.

In the wake of the Covid 19 outbreak, entire mankind across the globe is suffering. Enhancing the body's natural defence system (immunity) plays an important role in maintaining optimum health.

We all know that prevention is better than cure. While there is no medicine for COVID-19 as 
of now, it will be good to take preventive measures which boost our immunity in these times.

Ayurveda, being the science of life, propagates the gifts of nature in maintaining healthy and happy living. Ayurveda's extensive knowledge base on preventive care, derives from the concepts of "Dinacharya" - daily regimes and "Ritucharya" - seasonal regimes to maintain healthy life. It is a plant-based science. The simplicity of awareness about oneself, and the harmony each individual can achieve by uplifting and maintaining his or her immunity is emphasized across Ayurveda's classical scriptures.

Ministry of AYUSH recommends the following self-care guidelines for preventive health measures and boosting immunity with special reference to respiratory health. These are supported by Ayurvedic literature and scientific publications.

\section{$\underline{\text { Recommended Measures }}$}

\section{General Measures}

- 1. Drink warm water throughout the day.

- 2. Daily practice of Yogasana, Pranayama and meditation for at least 30 minutes as advised by Ministry of AYUSH (\#YOGAatHome \#StayHome \#StaySafe)

- 3. Spices like Haldi (Turmeric), Jeera (Cumin), Dhaniya (Coriander) and Lahsun (Garlic) are recommended in cooking.

\section{Ayurvedic Immunity Promoting Measures}

- 1. Take Chyavanprash 10gm (1 tsf) in the morning. Diabetics should take sugar free Chyavanprash.

- 2. Drink herbal tea / decoction (Kadha) made from Tulsi (Basil), Dalchini (Cinnamon), Kalimirch (Black pepper), Shunthi (Dry Ginger) and Munakka (Raisin) once or twice a day. Add jaggery (natural sugar) and / or fresh lemon juice to your taste, if needed.

- 3. Golden Milk- Half tea spoon Haldi (turmeric) powder in $150 \mathrm{ml}$ hot milk - once or twice a day.

\section{Simple Ayurvedic Procedures}

- 1. Nasal application - Apply sesame oil / coconut oil or Ghee in both the nostrils (Pratimarsh Nasya) in morning and evening.

- 2. Oil pulling therapy- Take 1 table spoon sesame or coconut oil in mouth. Do not drink, Swish in the mouth for 2 to 3 minutes and spit it off followed by warm water rinse. This can be done once or twice a day.

\section{During dry cough / sore throat}

- 1. Steam inhalation with fresh Pudina (Mint) leaves or Ajwain (Caraway seeds) can be practiced once in a day.

- 2. Lavang (Clove) powder mixed with natural sugar / honey can be taken 2-3 times a day in case of cough or throat irritation.

- 3. These measures generally treat normal dry cough and sore throat. However, it is best to consult doctors if these symptoms persist. 
1 The above measures can be followed to the extent possible as per an individual's convenience.

2 These measures are recommended by following eminent Vaidyas from across the Country as they may possibly boost an individual's immunity against infections.

Disclaimer: The above advisory does not claim to be treatment for COVID 19.

2.1.4 An advisory titled 'Advisory from Ministry of AYUSH for meeting the challenge. arising out of spread of Corona Virus (COVID-19) in India' dated '06th March 2020' is available on the website of Ministry of AYUSH, Government of India [20]. The details of this advisory and the Ayurvedic interventions suggested therein are as follows.

As you are aware, incidences of Corona Virus (COVID-19) have been reported worldwide and 30 positive cases of Corona Virus have also been reported in India till date. Even though there is no panic response warranted, AYUSH being one of the important Ministry equipped for providing appropriate response to the circumstances arose due to this public health challenge, it is worthwhile to associate with other Stake holders in eliciting AYUSH based public health response considering the strength and evidences of these systems. In the past also, interventions under AYUSH systems had been varyingly used for making an effective public health response in similar situations faced in many States/UTs.

Keeping in view, Ministry of AYUSH with the recommendations from Research Councils under its administrative control has come out with an advisory (Copy enclosed as AnnexureI) which may be communicated /implemented through AYUSH personnel and facilities as per the prevailing system of medicine in your State/UT.

These interventions from different AYUSH systems of medicine are supported with evidences from promotion of immunity and help in improving the respiratory symptoms in similar diseases. In this regard, a separate list of references is also enclosed at Annexure-II (given at the end of the advisory [20]).

\section{$\underline{\text { Annexure-I }}$}

Advisory from Ministry of AYUSH for meeting the challenge arising out of spread of Corona Virus (COVID-19) in India

Corona viruses $(\mathrm{CoV})$ are a large family of viruses that cause illness ranging from the common cold to more severe diseases such as Middle East Respiratory Syndrome (MERS$\mathrm{CoV}$ ) and Severe Acute Respiratory Syndrome (SARS-CoV). The new Corona virus disease (COVID-19) was first reported from Wuhan, China, on 31 December 2019. 72 countries reported COVID-19 incidence with 90,870 confirmed cases and 3112 deaths as per WHO factsheet as on 03.03.2020. As on 03.03.2020, 05 confirmed cases are reported in India from various parts.

Common signs of infection include fever, cough, myalgia, fatigue and breathing difficulties. In more severe cases, infection can cause pneumonia, severe acute respiratory syndrome, kidney failure and even death. 
The function of the immune system is critical in the human response to infectious disease. Viral infections induce oxidative stress and cause damage to airway epithelial cells. A growing body of evidence identifies stress, nutrition and immunity as a cofactor in infectious disease susceptibility and outcomes. The mainstay in management of corona viral infections has been supportive care, nutrition and preventing further progression in the absence of any antiviral agent or vaccine.

During Ebola outbreak in 2014 expert group of WHO has recommended that "it is ethical to offer unproven interventions with as yet unknown efficacy and adverse effects, as potential treatment or prevention" keeping in view no vaccine or anti-virals were available.

\title{
Approach of AYUSH systems:
}

The holistic approach of AYUSH systems of medicine gives focus on prevention through lifestyle modification, dietary management, prophylactic interventions for improving the immunity and simple remedies based on presentations of the symptoms.

For instance, emphasis on avoidance of causative factors and enhancing the immunity against host of infections are characteristics of Ayurveda management.

The AYUSH approach to manage the outbreak broadly comprise of:

i. Preventive and prophylactic

ii. Symptom management of COVID-19 like illnesses

iii. Add on Interventions to the conventional care

Based on potential \& strength of AYUSH systems supported by evidences for promotion of immunity and help in improving the respiratory symptoms in similar diseases and as per the recommendations from the research councils under Ministry of AYUSH following system wise approach is recommended:

\section{i. Preventive and prophylactic: Ayurveda:}

Samshamani Vati $500 \mathrm{mg}$. twice a day with warm water for 15 days. The medicine contains aqueous extract of Tinospora cordifolia.

\section{ii. Symptom management of COVID-19 like illnesses Ayurveda \\ 1. AYUSH-64 : 02 tablets twice a day \\ 2. Agasthya Hareetaki : 05 gm twice a day with warm water \\ 3. Anuthaila/Sesame oil 02 drops in each nostril daily in the morning}

All these medicines should be taken in consultation with qualified physicians of respective AYUSH systems.

\author{
iii. Add on Interventions to the conventional care \\ Ayurveda \\ 1. AYUSH-64 : 02 tablets twice a day \\ 2. Agastya Hareetaki: 05 gm twice a day with warm water
}


All these medicines should be taken in consultation with qualified physicians of respective AYUSH systems.

In addition, the following AYUSH specific measures may be adopted:

The diet should be fresh, warm, easy to digest, containing whole cereals, seasonal vegetables etc. Frequent sipping of water boiled with Tulsi leaves, crushed ginger, and turmeric would be beneficial. Honey with a pinch of pepper powder is also beneficial in case cough. Cold, frozen and heavy foods may be best avoided. It is always beneficial to avoid direct exposure to cold breeze. Appropriate rest and timely sleep are advisable. The practice of Yogasana and Pranayama under the guidance of qualified Yoga instructor is recommended.

Common medicinal plants useful in similar symptoms are Tulsi (Ocimum sanctum), Guduchi (Tinospora cordifolia), Ginger (Zingiber officinale) and Turmeric (Curcuma longa).

\subsection{Evidence based Ayurvedic management of various diseases}

(a) A book titled 'Evidence based ayurvedic practice - based on CCRAS R\&D contributions' is available on the website of Central Council for Research in Ayurvedic Sciences (CCRAS), Ministry of AYUSH, Government of India [21]. This book gives evidence based studies for the Ayurvedic treatment of the following diseases (which include respiratory diseases as well): Anaemia, Bronchial Asthma, Cardiovascular Disease, Diabetes, Peptic Ulcer, Epilepsy, Filariasis, Fistula-in-ano, Haemorrhoids, Hemiplegia, Hypertension, Malaria, Obesity and Lipid Disorders, Paraplegia, Psoriasis, Rheumatoid Arthritis, Sciatica, Urolithiasis.

(b) A book titled 'Drug development for select diseases - evidence based approach - based on CCRAS R\&D contributions' is available on the website of Central Council for Research in Ayurvedic Sciences (CCRAS), Ministry of AYUSH, Government of India [22]. This book gives evidence based studies for the development of Ayurvedic drugs for the following diseases and health conditions: Malaria, Epilepsy, Diabetes Mellitus, Psoriasis and Duodenal ulcer, Immunomodulatory, Anti-stress, General Health Promotion, Rheumatoid Arthritis, Ano Rectal disorders, Promotion of Health in Children, Diarrhoea and Fever in Children, Antenatal Care.

\subsection{Studies on the therapeutic efficacy of various Ayurvedic interventions and medicinal herbs for the management of diseases that have symptoms similar to those prevalent during present time}

This section reviews evidence based studies on the therapeutic efficacy of various Ayurvedic interventions and medicinal herbs for the management of diseases that have symptoms similar to those prevalent during present time. These diseases are Sinusitis, Allergic Rhinitis, Bronchitis, Bronchial Asthma and Pulmonary Tuberculosis (Table 1). 
Table 1: Evidence based studies on the therapeutic efficacy of various Ayurvedic interventions and medicinal herbs for the management of diseases that have symptoms similar to those prevalent during present time

\begin{tabular}{|c|c|c|c|c|}
\hline Disease & Ayurvedic Intervention & Sample & Result & Ref \\
\hline $\begin{array}{l}\text { Uncomplicated } \\
\text { chronic } \\
\text { sinusitis }\end{array}$ & $\begin{array}{l}\text { Tribhuvan kirti rasa (Tablet) } 250 \mathrm{mg} \\
\text { BD with Adrak swaras (juice of } \\
\text { ginger), steam inhalation of Dasamula- } \\
\text { kwath was administered twice a day } \\
\text { followed by nasya of Anu tailam (oil) at } \\
\text { a dose of } 4 \text { drops in both nostrils. } \\
\text { Duration - } 45 \text { to } 90 \text { days }\end{array}$ & 30 & $\begin{array}{l}\text { Overall clinical efficacy } \\
\text { was } 96.6 \% \\
\text { Intervention was found to } \\
\text { be well tolerated in general } \\
\text { and no side effects were } \\
\text { reported }\end{array}$ & {$[23]$} \\
\hline $\begin{array}{l}\text { Chronic } \\
\text { sinusitis } \\
\text { (dushta } \\
\text { pratishyaya) }\end{array}$ & $\begin{array}{l}\text { Group-A - Trayodashanga Kwatha with } \\
\text { Madhu given orally (45 days) } \\
\text { Group-B - Pradhamana Nasya with } \\
\text { Trikatu+Triphala Churna ( } 7 \text { sittings, on } \\
\text { alternate days) } \\
\text { Group-C - Initially Pradhamana Nasya } \\
\text { (7 sittings, on alternate days), followed } \\
\text { by oral administration of } \\
\text { Trayodashanga Kwatha with Madhu } \\
\text { (45 days) } \\
\text { Follow-up - } 1 \text { month for each group }\end{array}$ & $\begin{array}{l}31 \\
\text { A-10 } \\
\text { B-11 } \\
\text { C-10 }\end{array}$ & $\begin{array}{l}>75 \% \text { relief in symptoms: } \\
\text { A - } 8 \text { patients } \\
\text { B - } 9 \text { patients } \\
\text { C - } 6 \text { patients }\end{array}$ & {$[24]$} \\
\hline $\begin{array}{l}\text { Allergic } \\
\text { rhinitis } \\
\text { (pratishyaya) }\end{array}$ & $\begin{array}{l}\text { Group-A : Haridra khanda (Orally) - } \\
\text { 6gm twice a day } \\
\text { Group-B : Pippalyadi taila (Nasya) + } \\
\text { Haridra khanda (Orally) (Pippalyadi } \\
\text { taila 4-8 drops in each nostril, } 3 \text { sittings } \\
\text { of } 7 \text { days each with one week interval) } \\
\text { Follow-up - } 2 \text { months }\end{array}$ & $\begin{array}{l}26 \\
A-11 \\
B-15\end{array}$ & $\begin{array}{l}>75 \% \text { relief in symptoms: } \\
\text { A - } 5 \text { patients } \\
\text { B - } 8 \text { patients } \\
\\
>50 \% \text { relief in symptoms: } \\
\text { A - } 9 \text { patients } \\
\text { B }-14 \text { patients }\end{array}$ & {$[25]$} \\
\hline $\begin{array}{l}\text { Allergic } \\
\text { rhinitis } \\
\text { (anurjata janita } \\
\text { pratishyaya) }\end{array}$ & $\begin{array}{l}\text { Group-A - Shunthi taila Nasya for } 14 \\
\text { days, followed by internal drug Sudha } \\
\text { Haridra } 2 \text { gm TDS for } 21 \text { days } \\
\text { Group-B - Pradhamana Nasya with } \\
\text { Katphal churna till samayaka shuddhi } \\
\text { lakshana obtained, followed by internal } \\
\text { drug Shuddha Haridra } 2 \text { gm TDS for } \\
\text { 21days } \\
\text { Group-C - Oral drug Sudha Haridra } \\
\text { 2gm TDS for } 21 \text { days } \\
\text { Follow-up - } 1 \text { month for each group }\end{array}$ & $\begin{array}{l}63 \\
\text { A-19 } \\
\text { B-23 } \\
\text { C-21 }\end{array}$ & $\begin{array}{l}\text { Symptoms like sneezing, } \\
\text { rhinohorrea, headache, } \\
\text { itching were almost } \\
\text { completely relieved in all } \\
\text { the groups }\end{array}$ & {$[26]$} \\
\hline $\begin{array}{l}\text { Acute } \\
\text { bronchitis } \\
\text { (kaphaja kasa) }\end{array}$ & $\begin{array}{l}\text { Group-A : Haritaki Tablet with Usna } \\
\text { jala BD, for } 7 \text { days } \\
\text { Group-B : Saindhava Lavana Curna } \\
\text { with Usna jala BD, for } 7 \text { days } \\
\text { Group-C : Haritaki + Saindhava Lavana } \\
\text { (in equal quantity) with Usna jala BD, } \\
\text { for } 7 \text { days }\end{array}$ & $\begin{array}{l}19 \\
\text { A-6 } \\
\text { B-6 } \\
\text { C-7 }\end{array}$ & $\begin{array}{l}>90 \% \text { relief in the } \\
\text { symptoms in Group-C } \\
\text { Promising results in other } \\
\text { groups as well }\end{array}$ & {$[27]$} \\
\hline
\end{tabular}




\begin{tabular}{|c|c|c|c|c|}
\hline $\begin{array}{l}\text { Chronic } \\
\text { bronchitis }\end{array}$ & $\begin{array}{l}\text { Vyaghriharitaki avaleha - } 10 \mathrm{~g} \text { twice a } \\
\text { day with lukewarm water, before meals, } \\
\text { for } 12 \text { weeks } \\
\text { Follow-up - } 4 \text { weeks }\end{array}$ & 61 & $\begin{array}{l}\text { Significant relief in } \\
\text { wheezing, chest pain, sore } \\
\text { throat, nasal congestion, } \\
\text { dyspnoea and productive } \\
\text { cough was observed }\end{array}$ & [28] \\
\hline $\begin{array}{l}\text { Tamaka shvasa } \\
\text { (bronchial } \\
\text { asthma) }\end{array}$ & $\begin{array}{l}\text { Puskaramooladi choorna (powder) - } \\
\text { including Sati (Hedichum spicatum, } \\
\text { Rose), Puskaramoola (Innula racemosa, } \\
\text { Linn), and Amalaki (Emblica } \\
\text { officinalis, Gaertn) } \\
9 \text { gm powder was given in } 3 \text { divided } \\
\text { doses with honey - administered for } 6 \\
\text { weeks }\end{array}$ & 25 & $\begin{array}{l}\text { Significant improvement in } \\
\text { pulmonary function values } \\
\text { No adverse effects during } \\
\text { the course of the study }\end{array}$ & [29] \\
\hline $\begin{array}{l}\text { Bronchial } \\
\text { Asthma }\end{array}$ & $\begin{array}{l}\text { Shirishadi polyherbal compound } \\
\text { including Shirisha (Albizia lebbeck (L.) } \\
\text { Benth.), Nagarmotha (Cyperus } \\
\text { rotundus Linn.), and Kantkari } \\
\text { (Solanum xanthocarpum Schrad and } \\
\text { Wendl.) } \\
\text { Shirishadi Ayurvedic Nebulizer, } 2.5 \mathrm{mg} \\
(2.5 \mathrm{ml}) \text { twice in a day for first } 15 \text { days, } \\
\text { and then S.O.S., followed by oral } \\
\text { administration of Shirishadi Ghana Vati } \\
500 \mathrm{mg} \text { with lukewarm water, twice a } \\
\text { day, for } 1 \text { month }\end{array}$ & 20 & $\begin{array}{l}\text { Significant improvement in } \\
\text { the pulmonary function } \\
\text { with regards to dyspnea, } \\
\text { cough, expectoration, } \\
\text { wheezing, frequency of } \\
\text { attack, paroxysms of } \\
\text { dyspnea, PEFR, FVC, } \\
\text { FEV1 }\end{array}$ & [30] \\
\hline $\begin{array}{l}\text { Tamakashvasa } \\
\text { (bronchial } \\
\text { asthma) }\end{array}$ & $\begin{array}{l}\text { Group-A - treated with Ghanasattva of } \\
\text { Tamalaki (Phyllanthus fraternus } \\
\text { Webster), } 500 \mathrm{mg} \text {, thrice daily, orally, } \\
\text { for } 45 \text { days }\end{array}$ & 10 & $\begin{array}{l}\text { Significant improvement in } \\
\text { breathlessness, cough, } \\
\text { rhonchi, expectoration, } \\
\text { jaranashakti, ruchi and } \\
\text { wheezing }\end{array}$ & [31] \\
\hline $\begin{array}{l}\text { Tamaka shwasa } \\
\text { (bronchial } \\
\text { asthma) }\end{array}$ & $\begin{array}{l}\text { Nithyavirechana with Eranda thaila } \\
\text { (castor oil) in a dose of } 15-30 \mathrm{ml} \text {, once } \\
\text { a day, for first } 7 \text { days } \\
\text { Along with this, oral administration of } \\
\text { Nayopayam kashaya (including Bala } \\
\text { (Sida cardifolia), Jeeraka (Cumminum } \\
\text { cyminum), and Shunthi (Zingiber } \\
\text { officinale Rosc)) in a dose of } 50 \mathrm{ml}, \\
\text { twice a day, for } 28 \text { days }\end{array}$ & 20 & $\begin{array}{l}\text { Significant improvement in } \\
\text { breathlessness, cough, } \\
\text { speech, sputum, respiratory } \\
\text { rate, etc. }\end{array}$ & [32] \\
\hline $\begin{array}{l}\text { Tamaka swasa } \\
\text { (bronchial } \\
\text { asthma) }\end{array}$ & $\begin{array}{l}\text { Herbal Padmapatradi yoga (including } \\
\text { Padmapatra (Puskaramula) (Inula } \\
\text { recemosa hook), Bharangi } \\
\text { (Clerodendrum serratum), Malaya } \\
\text { Vacha (Alpinia galanga), Shati } \\
\text { (Hedychium Spicatum), Pippali (Piper } \\
\text { longum)) - Administered four tablets } \\
\text { (500 mg each) or } 2 \text { g per day in two } \\
\text { divided doses, with lukewarm water, } \\
\text { for } 1 \text { month }\end{array}$ & 40 & $\begin{array}{l}\text { Significantly effective in } \\
\text { reducing the severity of } \\
\text { attack, and increasing peak } \\
\text { expiratory flow rate, breath } \\
\text { holding time }\end{array}$ & [33] \\
\hline
\end{tabular}




\begin{tabular}{|c|c|c|c|c|}
\hline Tamaka shwasa & $\begin{array}{l}\text { This is a review article about the } \\
\text { efficacy of different formulations of } \\
\text { Vasa (Adhatoda vasica Linn.) for } \\
\text { Tamaka shwasa } \\
\text { Vasa Ghana (extract) - } 2 \text { gm, given } \\
\text { b.i.d. with water for } 21 \text { days } \\
\text { Vasa Ghrita (ghee - clarified butter) - } \\
10 \text { gm, given b.i.d. with water for } 21 \\
\text { days } \\
\text { Vasa Avaleha (swarasa / kwatha - } \\
\text { decoction) - } 10 \text { gm, given b.i.d. with } \\
\text { water for } 28 \text { days }\end{array}$ & - & $\begin{array}{l}\text { Significant improvement in } \\
\text { symptoms of } \\
\text { breathlessness, cough, } \\
\text { wheezing, rhinitis, throat } \\
\text { pain, etc. }\end{array}$ & {$[34]$} \\
\hline $\begin{array}{l}\text { Tamaka shwasa } \\
\text { (bronchial } \\
\text { asthma) }\end{array}$ & $\begin{array}{l}\text { Group-A - Vasa avaleha (including Vasa } \\
\text { (Adhatoda vasica Nees.), Sharkara } \\
\text { (sugar candy), Go-Ghrita (cow ghee - } \\
\text { clarified butter), Pippali (Piper longum } \\
\text { Linn.), Madhu (honey)) } \\
\text { Group-B - granules of Vasa avaleha } \\
\text { Dose - } 6 \text { g twice a day with lukewarm } \\
\text { water for the duration of } 28 \text { days } \\
\text { Follow-up - done after } 14 \text { days }\end{array}$ & $\begin{array}{l}\text { A-32 } \\
\text { B-34 }\end{array}$ & $\begin{array}{l}\text { Significant increase in peak } \\
\text { expiratory flow rate, breath } \\
\text { holding time, and decrease } \\
\text { in frequency of attacks, } \\
\text { absolute eosinophil count } \\
\\
\text { Withdrawal of modern } \\
\text { emergency drugs, } \\
\text { improved quality of life }\end{array}$ & {$[35]$} \\
\hline $\begin{array}{l}\text { Rajayakshma } \\
\text { (pulmonary } \\
\text { tuberculosis) }\end{array}$ & $\begin{array}{l}\text { Administration of Bhringarajasava as } \\
\text { complementary drug along with } \\
\text { Directly Observed Treatment Short - } \\
\text { course chemotherapy (DOTS) regime } \\
\text { Bhringarajasava includes Bhringaraja } \\
\text { (Eclipta prostrate Linn.), Haritaki } \\
\text { (Terminalia chebula Retz.), Pippali } \\
\text { (Piper longum Linn.), Jatiphala } \\
\text { (Myristica fragrance Houtt.), Lavanga } \\
\text { (Sygizium aromaticum Linn.), Twak } \\
\text { (Cinnamomum zeylanicum), Ela } \\
\text { (Elatteria cardamomum), Tamalapatra } \\
\text { (Cinnamomum tamala), Nagakesara } \\
\text { (Messua ferrea), and Gudam (old cane } \\
\text { jaggery) } \\
\text { Dose - 30 ml with equal quantity of } \\
\text { water, thrice a day, half an hour after } \\
\text { food } \\
\text { Duration: } 2-3 \text { months during the } \\
\text { intensive phase of DOTS } \\
\text { Follow-up: 6-8 months based on } \\
\text { treatment category }\end{array}$ & 30 & $\begin{array}{l}\text { Better, safer, and faster } \\
\text { relief provided by the } \\
\text { addition of Bhringarajasava } \\
\text { to DOTS }\end{array}$ & {$[36]$} \\
\hline
\end{tabular}

\section{Ethnobotanical Review of Medicinal Plants Used in Different Countries - Use of Herbal Fumigation for Various Diseases}

This section reviews the ethnobotanical use of herbal fumigation for various diseases in different countries (Table 2). 
Table 2: Ethnobotanical use of herbal fumigation for various diseases in different countries.

\begin{tabular}{|c|c|c|c|}
\hline $\begin{array}{l}\text { Location / } \\
\text { Country }\end{array}$ & Herbs Used & Disease / Application & Ref \\
\hline \multirow[t]{5}{*}{ Romania } & Anemone pulsatilla L. & Insomnia & \multirow[t]{5}{*}[37]{} \\
\hline & Aruncus dioicus (Walter) Fernald & Epilepsy, Insomnia & \\
\hline & Carlina acaulis L. & Fright & \\
\hline & Salix alba L. & Fright & \\
\hline & Gratiola officinalis L. & $\begin{array}{l}\text { Fright during sleep, Epilepsy, } \\
\text { Paralysis }\end{array}$ & \\
\hline \multirow[t]{7}{*}{ Sudan } & $\begin{array}{l}\text { Acacia nilotica subsp. adstringens } \\
\text { (Schum. \& Thonn.) Roberty }\end{array}$ & Cold and flu & \multirow[t]{7}{*}[38]{} \\
\hline & Acacia seyal Delile & Rheumatic pain & \\
\hline & Aristolochia bracteolata Lam. & Ear infection & \\
\hline & Combretum hartmannianum Schweinf. & Rheumatic pain & \\
\hline & $\begin{array}{l}\text { Leptadenia pyrotechnica (Forssk.) } \\
\text { Decne. }\end{array}$ & Rheumatic pain & \\
\hline & $\begin{array}{l}\text { Maerua pseudopetalosa (Gilg \& Gilg- } \\
\text { Ben.) DeWolf }\end{array}$ & Hypertension & \\
\hline & Terminalia brownii Fresen. & Rheumatic pain & \\
\hline \multirow[t]{3}{*}{ Myanmar } & Volkameria inermis L. & After childbirth & \multirow[t]{3}{*}[39]{} \\
\hline & Clausena excavata Burm.f. & Ulcerated nose & \\
\hline & Nicandra physalodes (L.) Gaertn. & Toothache & \\
\hline \multirow[t]{8}{*}{ Iran } & Astragalus hamosus L. & Headache & \multirow[t]{8}{*}[40]{} \\
\hline & Euphorbia helioscopia L. & Antiseptic environment & \\
\hline & Hyoscyamus niger L. & Eczema & \\
\hline & Marrubium cuneatum Russell. & Migraine & \\
\hline & Peganum harmala L. & Antiseptic environment & \\
\hline & Solanum nigrum L. & Eczema, Toothache & \\
\hline & Ziziphora cliniopodioides Lam. & Headache & \\
\hline & $\begin{array}{l}\text { Nerium oleander L. + Salix alba L. + } \\
\text { Persica vulgaris L. }\end{array}$ & Headache & \\
\hline \multirow[t]{3}{*}{ Ethiopia } & Echinops kebericho Mesfin & After childbirth & \multirow[t]{3}{*}[41]{} \\
\hline & $\begin{array}{l}\text { Otostegia fruticosa (Forssk.) Schweinf. } \\
\text { ex Penzig }\end{array}$ & Disinfectant & \\
\hline & Withania somnifera (L.) Dunal & Stomach ache & \\
\hline
\end{tabular}




\section{Studies indicating the efficacy of Yagya Therapy / Integrative Approach (including Yagya Therapy) in the management of symptoms of various disease conditions}

This section reviews the effectiveness of Yagya Therapy / Integrative approach (including Yagya Therapy) in the management of symptoms of various disease conditions (Table 3 ).

Table 3: Effectiveness of Yagya Therapy / Integrative approach (including Yagya Therapy) in the management of symptoms of various disease conditions.

\begin{tabular}{|c|c|c|c|}
\hline Disease & Intervention & Result & Ref \\
\hline $\begin{array}{l}\text { Pulmonary } \\
\text { tuberculosis }\end{array}$ & $\begin{array}{l}\text { Clinical study was done with } \\
\text { Yagya-therapy, which enables } \\
\text { pulmonary administration of plant } \\
\text { medicines }\end{array}$ & $\begin{array}{l}\text { Promising outcome was seen } \\
\text { in pulmonary tuberculosis } \\
\text { patients }\end{array}$ & $\begin{array}{l}{[42]} \\
(\mathrm{pg} . \\
85 \text { of } \\
[1])\end{array}$ \\
\hline Crohn's disease & $\begin{array}{l}\text { A case report about a male patient } \\
\text { suffering from symptoms similar to } \\
\text { those of Crohn's disease } \\
\text { Prescribed an integrated approach } \\
\text { including Yagya Therapy (using an } \\
\text { appropriate herbal formulation - } \\
\text { havan samagri), and some other } \\
\text { Ayurvedic interventions like } \\
\text { decoction of medicinal herbs, } \\
\text { dietary recommendations, etc. }\end{array}$ & $\begin{array}{l}\text { Relief in abdominal pain } \\
\text { Marked relief in constipation } \\
\text { No swelling in legs } \\
\text { Reduction in stiffness in legs } \\
\text { Inrease in strength in legs } \\
\text { Started walking on his own } \\
\text { Could change posture from } \\
\text { sitting to standing and vice } \\
\text { versa, on his own } \\
\text { Could change side while } \\
\text { lying down, on his own } \\
\text { Slight increase in weight }\end{array}$ & {$[43]$} \\
\hline $\begin{array}{l}\text { Acute myeloid } \\
\text { leukemia (AML) }\end{array}$ & $\begin{array}{l}\text { A case report about a female patient } \\
\text { suffering from symptoms associated } \\
\text { with AML } \\
\text { The patient was prescribed an } \\
\text { integrated approach including } \\
\text { Yagya Therapy (using an } \\
\text { appropriate herbal formulation - } \\
\text { hawan samagri), and some other } \\
\text { Ayurvedic interventions like } \\
\text { decoction of medicinal herbs, } \\
\text { Ayurvedic medicines, dietary } \\
\text { recommendations, etc. }\end{array}$ & $\begin{array}{l}\text { Full relief in breathlessness } \\
\text { Full relief in vomiting } \\
\text { Full relief in bleeding piles } \\
\sim 75 \% \text { relief in constipation } \\
\sim 75 \% \text { relief in loss of } \\
\text { appetite } \\
\sim 75 \% \text { relief in body pain } \\
\text { Notable relief }(\sim 50 \%) \text { in } \\
\text { other complaints like } \\
\text { sleeplessness, stress, } \\
\text { depression, etc. }\end{array}$ & {$[44]$} \\
\hline $\begin{array}{l}\text { - Breast cancer } \\
\text { (BC) } \\
\text { - Mouth cancer } \\
\text { (MC) } \\
\text { - Chronic } \\
\text { myeloid } \\
\text { leukemia (CML) }\end{array}$ & $\begin{array}{l}\text { Three case studies } \\
\text { Evaluated effect on quality of life } \\
\text { (QOL) using self-prepared 10-scale } \\
\text { questionnaire } \\
\text { Yagya Therapy prescribed as } \\
\text { supportive care along with } \\
\text { standard allopathic treatment }\end{array}$ & $\begin{array}{l}\text { Improvement in QOL after } \\
\text { taking Yagya Therapy for- } \\
12 \text { months - BC patient } \\
7 \text { months - MC patient } \\
2 \text { months - CML patient }\end{array}$ & {$[45]$} \\
\hline
\end{tabular}




\begin{tabular}{|c|c|c|c|}
\hline $\begin{array}{l}\text { Epileptic } \\
\text { seizures }\end{array}$ & $\begin{array}{l}\text { A case report about a male patient } \\
\text { suffering from epileptic seizures } \\
\text { since past } 13 \text { years } \\
\text { Prescribed an integrated approach } \\
\text { including Yagya Therapy (using an } \\
\text { appropriate herbal formulation - } \\
\text { hawan samagri), and some other } \\
\text { Ayurvedic interventions like } \\
\text { decoction of medicinal herbs, } \\
\text { Ayurvedic medicines, dietary } \\
\text { recommendations, etc. }\end{array}$ & $\begin{array}{l}\text { Earlier, patient experienced } \\
\text { seizure episodes, at least once } \\
\text { every } 7 \text { to } 10 \text { days } \\
\text { After starting the integrated } \\
\text { approach, patient did not } \\
\text { experience any seizure } \\
\text { episode up to his second visit, } \\
\text { i.e. for about } 54 \text { days } \\
\text { Also felt relief in complaint } \\
\text { of vibration in entire body }\end{array}$ & [46] \\
\hline $\begin{array}{l}\text { Epileptic } \\
\text { seizures }\end{array}$ & $\begin{array}{l}\text { A case report about a male patient } \\
\text { suffering from epileptic seizures } \\
\text { since about } 3 \text { years } \\
\text { Prescribed Yagya-Therapy, which } \\
\text { had to be taken along with the } \\
\text { ongoing allopathic medication }\end{array}$ & $\begin{array}{l}\text { Earlier, he had } \sim 8-10 \text { seizure } \\
\text { episodes annually } \\
\text { Subsequently, he did Yagya- } \\
\text { Therapy for } \sim 3.5 \text { years, } \\
\text { wherein only } 2 \text { to } 3 \text { episodes } \\
\text { occurred during the first year, } \\
\text { that too during sleep only, } \\
\text { and after that no seizures } \\
\text { were experienced }\end{array}$ & [47] \\
\hline $\begin{array}{l}\text { Sub-clinical } \\
\text { hypothyroidism } \\
\text { (SCH) }\end{array}$ & $\begin{array}{l}\text { A case study about a male patient } \\
\text { suffering from SCH since }>2 \text { years } \\
\text { Had been taking allopathic } \\
\text { medication for SCH, B } 12 \text { complex } \\
\text { and high blood pressure, but TSH } \\
\text { never became normal } \\
\text { Took Yagya Therapy for } 3 \text { months } \\
\text { as an add-on therapy }\end{array}$ & $\begin{array}{l}\text { TSH levels became normal } \\
(3.0 \mu / \mathrm{ml}) \\
\text { Low levels of B12 (238-326 } \\
\mathrm{pg} / \mathrm{ml}) \text { increased to upper } \\
\text { side of normal range ( } 1034 \\
\mathrm{pg} / \mathrm{ml}) \\
\text { Tiredness, weakness, sleep } \\
\text { issues were fully resolved }\end{array}$ & [48] \\
\hline $\begin{array}{l}\text { Osteoarthritis } \\
(\mathrm{OA}) \text { of the knee }\end{array}$ & $\begin{array}{l}\text { A case report about a male patient } \\
\text { suffering from OA in right knee } \\
\text { Prescribed an integrated approach } \\
\text { including Yagya Therapy (using an } \\
\text { appropriate herbal formulation - } \\
\text { havan-samagri), and some other } \\
\text { Ayurvedic interventions like } \\
\text { decoction of medicinal herbs, } \\
\text { Ayurvedic medicines, dietary } \\
\text { recommendations, etc. }\end{array}$ & $\begin{array}{l}\text { Full relief in excruciating } \\
\text { knee-pain and the resulting } \\
\text { limping gait } \\
\text { No problem in walking up to } \\
\text { half a kilometer } \\
\text { Could change posture from } \\
\text { sitting to standing, and vice- } \\
\text { versa without support } \\
\text { Could sit cross legged on the } \\
\text { floor without any discomfort }\end{array}$ & [49] \\
\hline $\begin{array}{l}\text { Obsessive- } \\
\text { Compulsive } \\
\text { Disorder (OCD) } \\
\text { and Poly Cystic } \\
\text { Ovarian Disease } \\
(\text { PCOD) }\end{array}$ & $\begin{array}{l}\text { A case report about a female patient } \\
\text { suffering from symptoms of OCD } \\
\text { (since past } 19 \text { years) and PCOD } \\
\text { Prescribed an integrated approach } \\
\text { including Yagya Therapy (using an } \\
\text { appropriate herbal formulation - } \\
\text { havan-samagri), and some other } \\
\text { Ayurvedic interventions like } \\
\text { decoction of medicinal herbs, }\end{array}$ & $\begin{array}{l}\text { Full relief in PCOD } \\
\text { Menses became regular } \\
\text { Full relief in vomiting } \\
\text { Normal blood pressure } \\
\sim 75 \% \text { relief in sleeplessness } \\
\sim 75 \% \text { relief in weakness } \\
\sim 75 \% \text { relief in loss of } \\
\text { appetite } \\
\text { Notable relief in stress }\end{array}$ & [50] \\
\hline
\end{tabular}


Ayurvedic medicines, dietary

recommendations, etc.

In one more case study ${ }^{\#}$, a female patient suffering from acute pulmonary edema and mild cardiomegaly, along with symptoms of severe breathlessness, low grade fever, node in the chest, sleeplessness, etc., was prescribed an integrated approach including Yagya Therapy (using an appropriate herbal formulation - havan samagri), and some other Ayurvedic interventions like decoction of medicinal herbs, Ayurvedic medicines, dietary recommendations, etc., which had to be taken alongside the already continuing allopathic treatment (which continued simultaneously for about 2.5 months). As per a feedback taken after about two years of starting the integrated approach, the patient had experienced complete relief in low grade fever, sleeplessness, body pain, loss of appetite, constipation and weakness; complaint of breathlessness was almost completely resolved; node in the chest had disappeared about seven months after starting the integrated approach.

${ }^{\#}$ Shrivastava V, Batham L, Mishra S, Mishra A. Application of an integrated approach including yagya therapy for the management of acute pulmonary edema with mild cardiomegaly. Ayurveda evam Samagra Swasthya Shodhamala. 2020;2(1):1. https://sites.google.com/dsvv.ac.in/shodhamala-dahh/asssm21/asssm211

\section{Ayurvedic perspective about epidemics and the therapeutic effect of Yagya / Herbs / Mantra as mentioned in ancient Vedic scriptures}

The ancient Indian texts of Ayurvedic system of medicine, Charaka Samhita (Vimana Sthana - Chapter 3) [5,7] and Sushruta Samhita [6,8,9], contain detailed discussion about epidemics, which has been mentioned therein as Janapadodhvansa.

\subsection{Causes and symptoms of epidemics}

\subsubsection{Details in Charaka Samhita}

Looking at the importance of this topic, Acharya Charaka has designated a full chapter to the same in Charaka Samhita (Vimana Sthana - Chapter 3) (from page 768 of [5]) that talks at length about the causes, symptoms, and relief measures for Janapadodhvansa (destruction of communities - depopulation through epidemics). The excerpts of the English translation of various verses are as follows.

The chapter begins with the declaration that it will describe the depopulation through epidemics (Charaka Vimana 3/1 - pg. 768 [5]).

The chapter begins by the statement that the stars, the planets, the moon, the sun, the wind, the temperature, etc. are presenting their abnormal aspect, thus pretending abnormal seasonal fluctuations. As a result of this abnormality, the earth will fail to produce the herbs having the right qualities of taste, potency, post-digestive effects, and specific action. In consequence of this failure, there will ensue a marked prevalence of disease (Charaka Vimana 3/4 - pg. $769[5])$. 
What are the symptoms in the nature and society that may lead to the occurrence of Janapadodhvansa (destruction of population)?

The factors that affect the people in common are (Charaka Vimana 3/6 - pg. 771 [5]):

- Wind

- Water

- Country

- Season

Next, the properties of wind, water, country and season are described that are diseaseinducing and foretell the occurrence of Janapadodhvansa (Charaka Vimana 3/7 - pg. 771-774 [5]). Some of these are as follows:

- Wind [5]

- Unseasonal

- Violently blowing

- Exceedingly rough

- Intensely cold

- Intensely hot

- Excessively dry

- Excessively humid

- Fearfully clamorous

- Blowing from contrary directions and clashing with itself

- Extremely rotatory

- Charged with unwholesome odors, moisture, sand, dust and smoke

- Water [5]

- Having an extremely aberrant smell, color, taste and touch

- Abounding with putrescent (decaying, rotting) matter

- Deserted by aquatic birds

- In which aquatic creatures are atrophied

- Which is unpleasant

- Country [5]

- Abounding in mosquitoes, flies, mice, etc.

- Woods of weeds

- Where winds are smoky

- Where animals and birds are always in a state of alarm and pain

- Where amidst the people - morality, truth, modesty, custom, character and virtue have either declined, or been given up

- Where waters are always agitated

- Frequently subjected to thunderbolts, earthquakes

- The sun, the moon and stars are frequently covered by dry, coppery, grey clouds

- Which is full of constant alarm and lamentation, crying, fright 
- Season [5]

- Has characteristics that are opposite to normal

The ascending scale of importance of these factors in causing Janapadodhvansa is:

Season $>$ Country $>$ Water $>$ Wind

by virtue of the degree of their indispensability (Charaka Vimana 3/9,10 - pg. 774 [5]).

What makes the wind, etc. inclement (unwholesome)?

The role of unrighteousness in the population is described here (Charaka Vimana 3/19 - pg. $776[5])$.

Answer: (Charaka Vimana 3/20 - pg. 777,778 [5])

The deterioration of the winds, etc. has its origin in the unrighteous deeds (Pragyaparadha (Charaka Sharira 1/98-109 [51]) - Adharma).

When the ruling authorities of the country, cities, trade-guilds, etc., govern the people irresponsibly by transgressing the law, then their subordinates, town-folks, village-folks, those who earn a living through some profession, tend to promote the growth of lawlessness. As a result, disorder swallows up all order. Thereafter, these people, are given up even by the Gods.

It is then that the seasons change adversely for these people, from whom the law has receded, whose actions have become unlawful, and who are foresaken by the Gods.

On account of this -

- The heavens rain, not in season, or never at all, or abnormally

- The winds do not blow rightly

- The earth is afflicted

- The waters dry up

- The herbs lose their true properties and suffer deterioration

In consequence, the people perish as the result of infectious contact or ingestion.

In the same manner, it is unrighteousness alone that is the cause of destruction of people by armaments (Charaka Vimana 3/21 - pg. 778 [5]):

- those who are moved by extravagant greed, anger, folly, or arrogance, despising the weak for the destruction of themselves, their people and the enemy

- come into armed conflict either among themselves or with others, or they themselves are attacked by others

The destruction that springs from a curse that has unrighteousness for its motive force - it is those who are guilty of dereliction of duty, that by disrespecting the preceptors, elders, seers, and the worshipful ones, act injuriously to themselves (Charaka Vimana 3/23 - pg. 779 [5]).

Being cursed by these preceptors and other - to perish in company with their kith and kin they are soon reduced to ashes.

Even in ancient times, calamities never resulted from any factor other than unrighteousness (Charaka Vimana 3/24 - pg. 779 [5]). 


\section{How does one disease affect all kinds of people?}

But, how does the simultaneous destruction of communities, consisting, as they do, of individuals who differ from one another in constitution, diet, physique, vitality, habits, psychic makeup, and age, take place by the incidence of one single disease? (Charaka Vimana $3 / 5$ - pg. $770[5])$ ?

Answer - Though a community may be heterogeneous in respect of the constitution, etc., of its individual members, there are other common factors (described above), which being adversely affected, will cause simultaneous outbreak of diseases having similar symptoms. It is these that devastate whole populations (Charaka Vimana 3/6 - pg. 771 [5]).

\subsubsection{Details in Sushruta Samhita}

The details with regards to Janapadodhvansa in Sushruta Samhita (Sutra Sthana Chapter 6 - Verse 19,20) (volume I - pg. 42 of [8]) (pg. 42 of [9]) are as follows (the disease symptoms are clearly mentioned here):

Sometimes even with regular seasons, the people of a country suffer through some sorcery, or some curse, or the wrath of evil spirits, or the wickedness (unrighteous behavior) of men; when the wind that blows into the country is vitiated by the odor of poisonous flowers and plants;

as a result, its people are attacked with:

- cough

- dyspnoea

- asthma

- vomiting

- nasal catarrh (common cold)

- headache

- fever, etc.

without any particular reference to the condition of their Doshas (humors) (at the time), but simply owing to the (noxious) influence of the planets, or lunar asterisms, or due to evil qualities in one's house, or furniture, or vehicles, or utensils, etc.

(Sushruta Sutra 6/19 [8,9]).

\subsection{Suggested management of diseases that affect people during epidemics}

Charaka Samhita (Vimana Sthana - Chapter 3) [5,7] and Sushruta Samhita [6,8,9], contain specific guidelines with regards to the treatment of diseases that affect people during Janapadodhvansa.

\subsubsection{According to Acharya Charaka (Charaka Vimana 3/8,13-18 [5])}

With a view to preserve life, the following things have been indicated as "medicine" in such terrible time (Charaka Vimana 3/15-18 - pg. 776 [5]):

- Truthfulness

- Compassion for creatures

- Charity 
- Sacrifices (of one's own vices, and not of any living creature)

- Worship of the Gods

- Observance of right conduct

- Tranquility

- (Prophylactic) protection of oneself

- Residing in a wholesome country

- Keeping of continence and the company of the continent

- Consulting the scriptures and the great self-restrained sages

- Constant association with the righteous, the well-dispositioned, and those who are approved of by the elders

There is no fear of diseases to those persons who are served with medicines that have been culled beforehand (Charaka Vimana 3/8 - pg. 774 [5]).

The purification procedure (consisting of emetics, purgatives, dry and unctuous enemata and errhine), is said to be the best of medicaments (Charaka Vimana 3/13 - pg. 775 [5]).

The rightful use of vitalising medications is recommended (Charaka Vimana 3/14 - pg. 775 $[5])$.

\subsubsection{According to Acharya Sushruta (Sushruta Sutra 6/20 [8,9])}

In such a case the impending evil may be turned into good by:

- Change of place of living

- (Performing) propitiatory or expiatory rites

- (Performing) auspicious rituals

- Hymn chanting

- Making oblations in the fire (ceremonies)

- (Righteous) offerings (to Gods)

- Dedications

- Donations

- Salutations with folded hands (to deities)

- Practicing devotion

- Practicing asceticism and penance

- Observance of restraints and vows

- Feeling kindness and compassion

- Offering charities

- Reception of mantras

- Following the advice of, and staying in company of (Gods, righteous people, and Gurus)

Any of these means may be resorted to with reference to Devas (Gods), or Brahmans (righteous people), or Gurus (spiritual guides).

By these, there will be great benefits (Sushruta Sutra 6/20 [8,9]). 


\subsubsection{Statements regarding the utility of herbs in treating diseases caused during epidemics}

\section{According to Acharya Charaka}

Therefore, well before such calamities occur, and well before the earth has lost her savour, collect the medicinal herbs while yet their taste, potency, post-digestive effects and specific actions remain unvitiated (Charaka Vimana 3/4 - pg. 769 [5]). We shall thus, when the occasion arises, make use of the taste, potency, post-digestive effects, and the specific actions of these herbs for the benefit of those who desire us, and also those whom we desire (Charaka Vimana 3/4 - pg. 769 [5]). Nor indeed, are counter-measures to epidemics that destroy populations, a difficult matter, provided the medicinal herbs are properly culled, properly prepared, and properly administered (Charaka Vimana 3/4 - pg. 770 [5]).

\section{According to Acharya Sushruta}

On the other hand, irregularity in the seasons occurs owing to fate / providential causes. Cold, heat, wind and rain, when they are irregular (either in amount or incidence), cause the herbs and water to become unwholesome, and their use produces all sorts of diseases (of mind and body), or even deadly epidemics. Hence, the use of wholesome herbs and water is recommended (for curing the diseases and epidemics) (Sushruta Sutra 6/16-18 [8,9]).

\subsection{How does Yagya incorporate the management measures suggested above?}

Most of the remedial measures suggested above by Acharya Charaka and Acharya Sushruta are covered in the methodology and philosophy of Yagya, which is an extremely ancient Indian therapeutic procedure $[1-4,10]$.

- (Performing) auspicious rituals - Yagya is an ancient auspicious ritual [10]

- Hymn chanting - Vedic hymns, that are intense spiritual prayers to God for the well being of the entire cosmos, are chanted in Yagya [1,10]

- Making oblations in the fire (ceremonies) - Oblations of mixture of medicinal herbs (havan samagri) are made in the fire of the Yagya for purification of environment and treatment of diseases $[1,10]$

- (Righteous) offerings (to Gods) - One of the basic feelings of Yagya [10]

- Dedications - One of the basic feelings of Yagya [10]

- Donations - One of the basic feelings of Yagya [10]

- Salutations with folded hands (to deities) - Several hymns that are chanted are heartfelt devout salutations $[10,11]$

- Practicing devotion - One of the basic feelings of Yagya [10]

- Practicing asceticism and penance - One of the basic feelings of Yagya [10]

- Observance of restraints and vows - The offering made to God under Deva Dakshina, wherein at least one vice is left, and at least one virtue is adopted in its place (pg. 48 of [10])

- Feeling kindness and compassion - One of the basic feelings of Yagya [10]

- Offering charities - One of the basic feelings of Yagya [10]

- Following the advice of, and staying in company of (Gods, righteous people, and Gurus) - One of the basic feelings of Yagya [10]

- The rightful use of vitalising medications is recommended - Efficient pulmonary 
inhalation of medicinal herbs, having therapeutic and rejuvenating properties, takes place during Yagya [1]

\subsection{References from ancient Vedic scriptures that describe the therapeutic effects of Yagya / Herbs / Mantra}

Ancient Vedic scriptures describe the treatment of wide range of diseases (both infectious and non-infectious) and restoration of good health through Yagya / Herbs / Mantra [52]. Some such references are compiled in Table 4.

Table 4: Treatment of various diseasesand restoration of good health through Yagya / Herbs / Mantra, as mentioned in ancient Vedic scriptures.

\begin{tabular}{|c|c|c|c|}
\hline Scripture & Verse & $\begin{array}{c}\text { Disease Treated / Improvement in Health / } \\
\text { Description }\end{array}$ & Ref \\
\hline Atharvaveda & $3 / 11 / 1,2$ & $\begin{array}{l}\text { Yagya cures Yakshma, Rajayakshma (symptoms similar } \\
\text { to Tuberculosis) patient, even from the last stage } \\
\text { condition }\end{array}$ & {$[53]$} \\
\hline Atharvaveda & $7 / 80 / 4$ & $\begin{array}{l}\text { Herbal medicines, mantras cure patient of Kshayaroga } \\
\text { (symptoms similar to Tuberculosis) }\end{array}$ & {$[53]$} \\
\hline Atharvaveda & $7 / 81 / 1$ & $\begin{array}{l}\text { In a house where Yagya is done, how can Kshayaroga } \\
\text { (symptoms similar to Tuberculosis) occur there? }\end{array}$ & {$[53]$} \\
\hline Atharvaveda & 9/13/10,11 & $\begin{array}{l}\text { Use of mantras to remove Yakshma roga (symptoms } \\
\text { similar to Tuberculosis) related toxins and associated } \\
\text { disorders from the body }\end{array}$ & {$[53]$} \\
\hline Atharvaveda & 9/13/19 & $\begin{array}{l}\text { Use of medicinal herbs to remove Yakshma roga } \\
\text { (symptoms similar to Tuberculosis) related toxins and } \\
\text { associated disorders from the body }\end{array}$ & {$[53]$} \\
\hline Atharvaveda & 20/96/6 & $\begin{array}{l}\text { Relief from Rajayakshma (symptoms similar to } \\
\text { Tuberculosis) and other unknown diseases through Yagya }\end{array}$ & {$[53]$} \\
\hline Atharvaveda & $9 / 13 / 20$ & $\begin{array}{l}\text { Use of mantras to remove the toxins related with Visalpa } \\
\text { (Peeda - pain), Vidradha (Soojan - swelling), Vataroga } \\
\text { (Vata related disorders) and Alaji (eye disorders) from } \\
\text { the body }\end{array}$ & {$[53]$} \\
\hline Atharvaveda & $6 / 90 / 2$ & $\begin{array}{l}\text { Use of medicinal herbs to detoxify different body parts } \\
\text { and veins of a patient suffering from pain (shoola rogi) }\end{array}$ & {$[53]$} \\
\hline Atharvaveda & $20 / 96 / 14$ & $\begin{array}{l}\text { Eradication of diseases that affect the fetus, with the help } \\
\text { of Fire God }\end{array}$ & {$[53]$} \\
\hline Atharvaveda & $3 / 11 / 3,4$ & $\begin{array}{l}\text { Havi (herbal oblation in Yagya) that provides longevity } \\
\text { has caused revival of the patient }\end{array}$ & {$[53]$} \\
\hline Atharvaveda & $20 / 96 / 8,10$ & $\begin{array}{l}\text { Provided protection to life by offering oblations (in } \\
\text { Yagya) meant for longevity - Brought back diseased } \\
\text { person from the clutches of death }\end{array}$ & {$[53]$} \\
\hline
\end{tabular}




\begin{tabular}{|l|l|l|l|}
\hline Atharvaveda & $8 / 1 / 3$ & $\begin{array}{l}\text { Use of mantras to provide relief from diseases that cause } \\
\text { deterioration of health }\end{array}$ & {$[53]$} \\
\hline Rigveda & $1 / 72 / 6$ & $\begin{array}{l}\text { Protection of Jivani-Shakti (vital life force) through } \\
\text { Yagya }\end{array}$ & [54] \\
\hline Atharvaveda & $5 / 23 / 4,5,8,10$ & $\begin{array}{l}\text { Different kinds of harmful worms are destroyed by } \\
\text { mantras }\end{array}$ & {$[53]$} \\
\hline Atharvaveda & $5 / 23 / 11$ & $\begin{array}{l}\text { Different kinds of harmful worms are destroyed by } \\
\text { mantras and medicinal herbs }\end{array}$ & {$[53]$} \\
\hline
\end{tabular}

\section{Conclusion}

Yagya has been one of the core elements of the ancient Indian Culture ever since the Vedic era, and is also an effective therapeutic procedure. The present review article explored the applicability of Yagya during the present time, as a therapeutic procedure for the management of respiratory ailments. Based on the information presented herein, the applicability of Yagya in the present time seems to be a promising possibility, that is worth exploring further through proper experimentation and analysis.

\section{Acknowledgements}

Authors would like to acknowledge the subtle guidance of their spiritual guide, Revered Pandit Shriram Sharma Acharya (http://www.awgp.org/about_us/patron_founder), who founded the organization - All World Gayatri Pariwar. Authors express their sincere gratitude and reverence for all those who have contributed to the development of this extraordinary science of Yagya for the welfare of humanity and nature, from the ancient times till the present date.

\section{Conflict of interest}

The authors declare that they have no conflict of interest.

\section{References}

1. Pandya P. Applied science of yagya for health and environment. Haridwar, Uttarakhand, India: Vedmata Gayatri Trust, Shantikunj; 2009. [cited 2020 March 25].

Available from: http://literature.awgp.org/book/Applied_Science_of_Yagya_for_Health_and_Environ ment/v1.1

2. Brahmavarchas. Yagya chikitsa (Hindi). Haridwar, Uttarakhand, India: Shri Vedmata Gayatri Trust (TMD), Shantikunj; 2016.

3. Brahmavarchas. Yagya ka gyan-vigyan (Hindi). Pandit Shriram Sharma Acharya samagra vangamaya. volume 25. Mathura, Uttar Pradesh, India: Akhand Jyoti Sansthan; 1998.

4. Brahmavarchas. Yagya - ek samagra upachar prakriya (Hindi). Pandit Shriram Sharma Acharya samagra vangamaya. volume 26. revised ed. Mathura, Uttar Pradesh, India: Akhand Jyoti Sansthan; 2012. 
5. The caraka samhita - volume II. Jamnagar, India: Shree Gulabkunverba Ayurvedic Society; 1949. [cited 2020 March 23]. Available from: https://archive.org/details/CharakSamhitaVol21949HindiEnglishGujaratGhulabKunw arAyurvedicSociety/page/n801/mode/2up

6. Lal K. The sushruta samhita - vol. I - sutrasthanam. Calcutta, India: Kaviraj Kunja Lal Bhishagratna; 1907. [cited 2020 March 23]. Available from: https://archive.org/details/dli.bengal.10689.3279/page/n147/mode/2up

7. Sharma PV. Charaka-samhita (text with English translation). volume I, II. Varanasi, Uttar Pradesh, India: Chaukhambha Orientalia; 2008.

8. Murthy KRS. Susruta samhita - Vol. I, II, III. Varanasi, Uttar Pradesh, India: Chaukhambha Orientalia; 2008.

9. Translation of the Sucruta. Hoernle AFR (translator). Calcutta, India: Asiatic Society of Bengal; 1897. [cited 2020 March 24]. Available from: https://archive.org/details/sushrutasamhitahoernlea.f.r.asiaticsociety1897blankafterpag e98_521_x/page/n51/mode/2up

10. Sharma $\overline{\mathrm{S}}$. Form and spirit of vedic ritual worship procedure of yagya. Poddar K, Shambhudass (translator). Haridwar, Uttarakhand, India: Shantikunj. [cited 2020 March 25]. Available from: https://archive.org/details/procedure-of-yagya-panditshriram-sharma-acharya/mode/2up

11. Sharma S. Eternity of sound and the science of mantras. Haridwar, Uttarakhand, India: Shantikunj. [cited 2020 March 29]. Available from: http://literature.awgp.org/book/Eternity_of_Sound_and_The_Science_of_Mantras/v1. 1

12. Sharma S. The astonishing power of bio-physical and subtle energies of human body. Joshi R, Shambhudass (translator). Haridwar, Uttarakhand, India: Vedmata Gayatri Trust (TMD), Shantikunj; 2012. [cited 2020 March 25]. Available from: https://archive.org/details/theastonishingpowerofbiophysicalandsubtleenergiesofhuma nbodybypanditshriramsharmaacharya2012/mode/2up

13. Sharma S. Wonders of human bioelectricity. Sahay TN (translator). Haridwar, Uttarakhand, India: Vedmata Gayatri Trust (TMD), Shantikunj; 2012. [cited 2020 March 25]. Available from: https://archive.org/details/wondersofhumanbioelectricitybypanditshriramsharmaachar ya2012/mode/2up

14. Sieler R. Kalari and vaittiyacalai: medicine and martial arts intertwined. Asian Medicine. 2012; 7(1): 164-195. https://doi.org/10.1163/15734218-12341247.

15. Muktibodhananda S. Hatha yoga pradipika - light on hatha yoga. 3rd ed. (Guidance of) Saraswati SS. Munger, Bihar, India: Yoga Publications Trust; 2006. [cited 2020 April 12]. Available from: https://archive.org/details/hathayogapradipikaswamimuktibodhananda_202003_329_ Y/mode/2up

16. Murthy KRS. Bhavaprakasa of bhavamisra. volume 1 - including nighantu portion. Varanasi, Uttar Pradesh, India: Chowkhamba Krishnadas Academy; 2016.

17. Ayurvedic advocacy for management of nipah virus (NiV) infection. In: Website of Central Council for Research in Ayurvedic Sciences (CCRAS), Ministry of AYUSH, Government of India. [cited 2020 April 17]. Available from: http://www.ccras.nic.in/sites/default/files/Notices//25052018_CCRAS_HQ_nipahviru s.pdf 
18. Ayurvedic perspective of swine flu. In: Website of National Health Portal (NHP), Centre for Health Informatics, National Institute of Health and Family Welfare, Ministry of Health and Family Welfare, Government of India; 2015. [cited 2020 April 17]. Available from: https://www.nhp.gov.in/ayurvedic-perspective-of-swine-flu_mtl

19. Ayurveda's immunity boosting measures for self care during COVID 19 crisis. In: Website of Ministry of AYUSH, Government of India; 2020. [cited 2020 April 17]. Available from: http://ayush.gov.in/docs/123.pdf

20. Advisory from Ministry of AYUSH for meeting the challenge arising out of spread of Corona Virus (COVID-19) in India. 6th March 2020. In: Website of Ministry of AYUSH, Government of India; 2020. [cited 2020 April 20]. Available from: https://www.ayush.gov.in/docs/125.pdf

21. Evidence based ayurvedic practice - based on CCRAS R\&D contributions. New Delhi, India: Central Council for Research in Ayurvedic Sciences (CCRAS), Ministry of AYUSH, Government of India; 2014. [cited 2020 April 17]. Available from: http://www.ccras.nic.in/sites/default/files/ebooks/Evidence-based\%20Ayurvedic $\% 20$ Practice/index.html

22. Drug development for select diseases - evidence based approach - based on CCRAS R\&D contributions. New Delhi, India: Central Council for Research in Ayurvedic Sciences (CCRAS), Ministry of AYUSH, Government of India; 2016. [cited 2020 April 17]. Available from: http://www.ccras.nic.in/sites/default/files/ebooks/Drug \%20development\%20for\%20select\%20diseases/index.html

23. Panigrahi HK. Efficacy of ayurvedic medicine in the treatment of uncomplicated chronic sinusitis. Ancient Science of Life. 2006; XXVI(1\&2): 6-11. https://www.ncbi.nlm.nih.gov/pmc/articles/PMC3335227/

24. Chaudhari V, Rajagopala M, Mistry S, Vaghela DB. Role of pradhamana nasya and trayodashanga kwatha in the management of dushta pratishyaya with special reference to chronic sinusitis. Ayu. 2010; 31(3): 325-331. https://doi.org/10.4103/09748520.77165 .

25. Bhakti C, Rajagopala M, Shah AK, Bavalatti N. A clinical evaluation of haridra khanda and pippalyadi taila nasya on pratishyaya (allergic rhinitis). Ayu. 2009; 30(2): 188-193. http://www.ayujournal.org/article.asp?issn $=0974-$ 8520 ; year $=2009 ;$ volume $=30 ;$ issue $=2 ;$ spage $=188$; epage $=193$; aulast $=$ Bhakti; type $=0$

26. Modha NJ (Tank), Shukla VD, Baghel MS. Clinical study of anurjata janita pratishyaya (allergic rhinitis) and comparative assessment of nasya karma. Ayu. 2009; 30(1): $\quad 47-54 . \quad \mathrm{http}: / / \mathrm{www}$.ayujournal.org/article.asp?issn=09748520 ; year $=2009$; volume $=30 ;$ issue $=1$; page $=47$; epage $=54$; aulast $=$ Modha; type $=0$

27. Rout AK, Dwivedi RR. A clinical study of haritaki and saindhava lavana in kaphaja kasa with special reference to samyoga guna. Ayu. 2011; 32(3): 357-360. https://doi.org/10.4103/0974-8520.93914.

28. Ram J, Baghel MS. Clinical efficacy of vyaghriharitaki avaleha in the management of chronic bronchitis. Ayu. 2015; 36(1): 50-55. https://doi.org/10.4103/09748520.169009.

29. Sai PAJV, Ratna M, Upadhyaya BN, Appaji RR. A clinical study on the use of puskara mooladi choorna in tamaka shvasa (bronchial asthma) with pulmonary function tests. $\begin{array}{lllll}\text { Ancient Science } & \text { of }\end{array}$ https://www.ncbi.nlm.nih.gov/pmc/articles/PMC3336280/

30. Kajaria D, Tripathi J, Tiwari S. Anti-asthmatic effect of shirishadi compound through nasal spray actuation. Ayu. 2014; 35(3): 261-269. https://doi.org/10.4103/09748520.153738 . 
31. Sen B, Dubey SD, Singh VP, Tripathi K. A study on shvasahara karma of tamalaki (phyllanthus fraternus webster). Ayu. 2009; 30(1): 42-46. http://www.ayujournal.org/article.asp?issn $=0974-$ 8520 ; year $=2009$; volume $=30$; issue $=1$; spage $=42$; epage $=46$; aulast $=$ Sen;type $=0$

32. Prasad MS, Ramachandran AP, Acharya GS, Shrilatha KT. Evaluation of the role of nithyavirechana and nayopayam kashaya in tamaka shwasa. Ayu. 2010; 31(3): 294299. https://doi.org/10.4103/0974-8520.77151.

33. Panda AK, Doddanagali SR. Clinical efficacy of herbal padmapatradi yoga in bronchial asthma (tamaka swasa). Journal of Ayurveda and Integrative Medicine. 2011; 2(2): 85-90. https://www.ncbi.nlm.nih.gov/pmc/articles/PMC3131777/.

34. Gupta A, Prajapati PK. A clinical review of different formulations of Vasa (Adhatoda vasica) on Tamaka Shwasa (asthma). Ayu. 2010; 31(4): 520-524. https://doi.org/10.4103/0974-8520.82032.

35. Paneliya AM, Patgiri B, Galib R, Prajapati PK. Efficacy of vasa avaleha and its granules on tamaka shwasa (bronchial asthma): open-label randomized clinical study. Ayu. 2015; 36(3): 271-277. https://doi.org/10.4103/0974-8520.182760.

36. Dornala SN, Dornala SSN. Clinical efficacy of bhringarajasava as naimittika rasayana in rajayakshma with special reference to pulmonary tuberculosis. Ayu. 2012; 33(4): 523-529. https://doi.org/10.4103/0974-8520.110536.

37. Petran M, Dragos D, Gilca M. Historical ethnobotanical review of medicinal plants used to treat children diseases in Romania (1860s-1970s). Journal of Ethnobiology and Ethnomedicine. 2020; 16: 15. https://doi.org/10.1186/s13002-020-00364-6.

38. Issa TO, Mohamed YS, Yagi S, Ahmed RH, Najeeb TM, Makhawi AM, Khider TO. Ethnobotanical investigation on medicinal plants in Algoz area (South Kordofan), Sudan. Journal of Ethnobiology and Ethnomedicine. 2018; 14: 31. https://doi.org/10.1186/s13002-018-0230-y.

39. DeFilipps RA, Krupnick GA. The medicinal plants of Myanmar. PhytoKeys. 2018; 102: 1-341. https://doi.org/10.3897/phytokeys.102.24380.

40. Tahvilian R, Shahriari S, Faramarzi A, Komasi A. Ethno-pharmaceutical formulations in Kurdish ethno-medicine. Iranian Journal of Pharmaceutical Research. 2014; 13(3): 1029-1039. https://www.ncbi.nlm.nih.gov/pmc/articles/PMC4177625/

41. d'Avigdor E, Wohlmuth H, Asfaw Z, Awas T. The current status of knowledge of herbal medicine and medicinal plants in Fiche, Ethiopia. Journal of Ethnobiology and Ethnomedicine. 2014; 10: 38. https://doi.org/10.1186/1746-4269-10-38.

42. Raghuvanshi M, Pandya P, Joshi RR. Yagyopathic herbal treatment of pulmonary tuberculosis symptoms - a clinical trial. Alternative and Complementary Therapies. 2004; 10(2): 101-105. https://doi.org/10.1089/107628004773933352.

43. Shrivastava V, Batham L, Mishra S, Mishra A. An integrated traditional therapy approach involving yagya therapy in patient with symptoms similar to crohn's disease. Interdisciplinary Journal of Yagya Research. 2019; 2(2): 11-19. https://doi.org/10.36018/ijyr.v2i2.26.

44. Shrivastava V, Batham L, Mishra S, Mishra A. Supportive care in a patient with acute myeloid leukemia through an integrated approach including yagya therapy. Interdisciplinary Journal of Yagya Research. 2019; 2(2): 20-28. https://doi.org/10.36018/ijyr.v2i2.27.

45. Mishra A, Batham L, Shrivastava V. Yagya Therapy as supportive care in cancer patients improved quality of life: case studies. Interdisciplinary Journal of Yagya Research. 2018; 1(1): 26-33. http://ijyr.dsvv.ac.in/index.php/ijyr/article/view/3 
46. Mishra A, Batham L, Verma S, Mishra S, Shrivastava V. Management of epileptic seizures through an integrated approach including yagya therapy. Interdisciplinary Journal of Yagya Research. 2019; 2(1): 52-64. http://ijyr.dsvv.ac.in/index.php/ijyr/article/view/24

47. Batham L, Choudhary L, Mishra A, Shrivastava V. Yagya therapy for epileptic seizures: a case study. Interdisciplinary Journal of Yagya Research. 2018; 1(2): 37-42. http://ijyr.dsvv.ac.in/index.php/ijyr/article/view/14

48. Verma S, Kumar P, Mishra A, Shrivastava V. Yagya therapy for sub-clinical hypothyroidism: a case study. Interdisciplinary Journal of Yagya Research. 2018; 1(2): 31-36. http://ijyr.dsvv.ac.in/index.php/ijyr/article/view/13

49. Mishra A, Batham L, Verma S, Mishra S, Shrivastava V. Management of the symptoms associated with osteoarthritis of the knee through an integrated approach including yagya therapy. Interdisciplinary Journal of Yagya Research. 2019; 2(2): 2937. https://doi.org/10.36018/ijyr.v2i2.25.

50. Shrivastava V, Batham L, Mishra S, Mishra A. Management of symptoms associated with obsessive-compulsive disorder (OCD) and polycystic ovarian disease (PCOD) through an integrated approach including yagya therapy. Interdisciplinary Journal of Yagya Research. 2019; 39-51. http://ijyr.dsvv.ac.in/index.php/ijyr/article/view/28

51. The caraka samhita - volume III. Jamnagar, India: Shree Gulabkunverba Ayurvedic Society; 1949. [cited 2020 March 23]. Available from: https://archive.org/details/CharakSamhitaVol31949HindiEnglishGujaratGhulabKunw arAyurvedicSociety/page/n51/mode/2up

52. Verma S, Mishra A, Shrivastava V. Yagya therapy in vedic and ayurvedic literature: a preliminary exploration. Interdisciplinary Journal of Yagya Research. 2018; 1(1): 1520. http://ijyr.dsvv.ac.in/index.php/ijyr/article/view/7

53. Sharma S, Sharma BD. Atharvaveda samhita - saral Hindi bhavarth sahit - part 1 to 2 (Hindi). Gayatri Tapobhumi, Mathura, Uttar Pradesh, India: Yug Nirman Yojna Vistar Trust; 2014.

54. Sharma S, Sharma BD. Rigveda samhita - saral Hindi bhavarth sahit - part 1 to 4 (Hindi). Gayatri Tapobhumi, Mathura, Uttar Pradesh, India: Yug Nirman Yojna Vistar Trust; 2014. 